\author{
Błażej Osowski \\ Adam Mickiewicz University in Poznań \\ Institute of Polish Philology \\ ORCID: 0000-0002-4226-1378; e-mail: blazej.osowski@amu.edu.pl
}

\title{
Selected aspects of the existence of Slavic dialects in the Internet ${ }^{1}$
}

\begin{abstract}
The research material pertains to rural and urban subdialects and dialects of nearly all the Slavic languages spoken in Belarus, Bulgaria, the Czech Republic, Macedonia, Poland, Serbia, Slovakia, Ukraine. The article consists of a theoretical part (dedicated to linguistic research into the Internet, computer-mediated communication) and of two analytical parts. The first of them, more general, is aimed at defining the codes used on the surveyed fan pages and the reasons for creating thereof. The goal of the other analytical part, which consists of detailed considerations, is to present the structure of dictionary posts by using Dawniej tutej - gwara wielkopolska, one of the oldest Polish fan pages dedicated to subdialects.
\end{abstract}

Key words: subdialect, Internet, Slavic languages, Slavic dialects, new media.

\begin{abstract}
Abstrakt: Wybrane aspekty funkcjonowania gwar słowiańskich w Internecie. Materiał badawczy dotyczy gwar wiejskich i miejskich oraz dialektów niemal całej Słowiańszczyzny: z terenu Białorusi, Bułgarii, Czech, Macedonii, Polski, Serbii, Słowacji, Ukrainy. Artykuł składa się z części teoretycznej poświęconej badaniom językoznawczym nad siecią i komunikacji komputerowej oraz dwóch części analitycznych. Pierwsza, o charakterze ogólnym, ma za cel określenie kodów używanych na badanych fanpage’ach oraz motywacji ich zakładania. Cel drugiej części analitycznej, mającej charakter rozważań szczegółowych, to omówienie budowy postów słownikowych na przykładzie jednego z najstarszych, polskich fanpage’y poświęconych tematyce gwarowej Dawniej tutej - gwara wielkopolska.
\end{abstract}

Słowa kluczowe: gwara, Internet, języki słowiańskie, dialekty słowiańskie, nowe media.

\section{Introduction}

Dialects and the Internet are seemingly unrelated phenomena. However, the Internet has become another dimension of reality, attracting forms which are new and typical of this medium or known from the "real" world. Among the activities taking place

1 This text is an extended and modified version of B. Osowski, Gwary słowiańskie w nowym środowisku komunikacyjnym - Internet, [in:] Z polskich studiów slawistycznych, series 13, vol. 2: Językoznawstwo, Z. Greń (ed.), Prace na XVI Międzynarodowy Kongres Slawistów w Belgradzie 2018, Poznań 2018, pp. 223-232. 
in the Internet are fan pages dedicated to dialects. (The status of dialects in the Internet has been marginalised following S. Dubisz's appeal to adopt not only dialectal systems but also dialectal features operating in the communication and stylistic varieties of the Polish language as a subject of a dialectological description (Dubisz 2013, 54)).

The material has been selected according to the name of the fan page (e.g. containing the word subdialect, dialect or another Slavic equivalent), its description and information about it, and the associations (links) with the already analysed pages. The research material pertains to rural and urban subdialects and dialects ${ }^{2}$ of nearly all Slavic languages, spoken in Belarus, Bulgaria, the Czech Republic, Macedonia, Poland, Serbia, Slovakia, Ukraine. Attempts at finding Russian material have proved futile, perhaps because of the existence of Vkontakte, a Russian equivalent of Facebook. The same holds true for Croatian, Sorbian and Slovenian. The specific subdialects and dialects will be represented to various degrees.

The article consists of a theoretical part (dedicated to linguistic research into the Internet, computer-mediated communication) and of two analytical parts. The first of them, more general, is aimed at defining the codes used on the surveyed fan pages and the reasons for creating thereof. While an analysis of the Web should take into consideration the relations between the producers and users of materials posted online (Schneider, Foot 2008, 28), due to the size of the text and for clarity purposes, the analysis has been limited to the contents uploaded by the creators of the fan pages. The goal will be accomplished by using the data included in the Description and Information parts of each analysed page. However, if the data were not provided (6 fan pages), we analysed the page title.

The goal of the other analytical part, which consists of detailed considerations, is to present the structure of dictionary posts by using Dawniej tutej - gwara wielkopol$s k a$, one of the oldest Polish fan pages dedicated to subdialects ${ }^{3}$. While the starting point is the theory of traditional lexicography, the material shows that in many cases it is not sufficient. This is because the Internet adapts and develops classical forms. Bearing in mind the popularity of the Dawniej tutej... fan page and the fact that its creator is not a professional linguist, the way in which dictionary posts are developed may be an indication for professional lexicographers as pinpointed by amateur dictionary compilers and their audiences.

\footnotetext{
2 The creators of the surveyed pages are oftentimes amateurs without linguistic knowledge hence they make mistakes in naming varieties of language.

${ }^{3}$ It was established in 2013 and it boasts 42,000 users. As the authors have informed us, it was established to propagate the Kościan variety of the Poznań subdialect. The posts published on the fan page typically take the form of online memes introduced by a short copy. (The above data come from the Information section of the analysed fan page).
} 


\section{The Web as a subject of linguistic research}

The emergence of the Internet followed by its popularisation have contributed to the various changes in contemporary societies. Among the most serious consequences of the phenomenon is communication established by entities which are dispersed at the same time and in unlimited space (Bugajski 2010, 143). Therefore, one of the basic features of dialects has been questioned, namely the factor of geographic diversity and being embedded in a specific space. This is the reason of J. Grzenia's doubts if subdialects could emerge in the Internet:

In natural conditions, spatial limitations in communication lead to the emergence of folk subdialects. However, this type of language varieties cannot emerge in the Internet due to its global nature; however, they can surface in the environment of a variety of a language. As a result, numerous sociolects are created, basically revolving around the conversational variety of online communication (Grzenia 2006, 116).

However, the names of fan pages like Gwara Zagłębiowska dla Ciućmoków; Górole Żywieccy - Hej gronicki, gronicki, Wy muoje kuochane; Moravština; Razmaulaj Pa Prostu; Брациговски диалект and the texts they present, e.g. fes szczuny z eki se nie wlywajom! (Dawniej tutej, 3 March 2017, com. ${ }^{4}$ ); Dáme si erteple s tatarkó šušniflintové? (Moravstina, 6 February 2017); NA SCHÔDKACH PÉRED SKLÉPOM SIDIÊLI OTRÓKI I CHLÍSTALI PÍVO; KORÓVA PÁRA RÁZY CHLISNÚEA VODÝ I BÔLŠ NE SCHOTIÊEA (Svoja, 6 March 2017) are evidence of the existence of subdialects in the Internet.

However, it is impossible to ignore the fact that back in 2005, D. Crystal mentioned the practical use of the Internet and the applied perspective, including preservation of minority and endangered languages. In the existing linguistic and social situation, they include also subdialects:

Firstly, it aids documentation, because digital techniques allow the easy recording of ethnological material - and, of prime importance, doing so using a technology which the teenage generation think of as 'cool'. The teenagers, after all, are the critical generation for any endangered language, as they are the parents of the next generation of speakers, and if their interest goes, the language is lost. Secondly, the Internet aids language revitalisation, by enabling speakers separated by space to maintain a virtual contact through email, chat, and instant messaging environments, and there are some very lively interactions out there now (Crystal 2005, 3).

It seems that the presented examples of subdialects in the Internet are evidence of seizing the opportunities described by D. Crystal. The analysis will not cover all

\footnotetext{
${ }^{4}$ When I quote online sources, the original spelling is presented. When I quote comments from a fan page, the abbreviation com. means quoting a comment; lack of that abbreviation means that I quote a post.
} 
the manifestations of dialects online but only the ones existing on fan pages. A fan page is

a place in the Web where the Internet users meet virtually because, for example, they share opinions and interests or are enthusiasts of a person or group. The software developers (...) of Facebook have developed a characteristic type of fan pages. They consist of:

- a board where the users exchange their views and share links to other websites,

- a gallery or a place where photos, memes etc. are made available,

- applications for carrying out opinion polls etc. (Cemborowski 2014, 92).

This definition of a fan page reflects the diversity and integration of the forms carrying messages. In that collection, the analysis has been limited to the following texts:

- a social post - (typically) a short form aimed at sharing the latest news, links, information, where multimedia can be posted (photos, video or audio recordings); it can be commented on by the readers (Chyrzyńki 2012, 115-116);

- comments - opinions posted by website readers; they refer to the main text or other comments and often lead to an extended discussion whose structure is reminiscent of a tree of threads in a discussion forum (Chyrzyński 2012, 112-113); it can contain multimedia and links; the copy and the comment are both referred to as a post;

- a thread - a series of opinions of discussion participants within a forum, letters, a discussion group or in a social networking service; it is hierarchical with the person starting the thread as the highest in the hierarchy although a change of subject is possible and the participants can refer to the statements of the other users (Chyrzyński 2012, 115);

and graphic elements containing copy:

- an online meme - a digitalized unit of information (an image, a video, a website, a slogan, hyperlinks) distributed online (Kowalewska 2015, 183); typically memes are associated with online jokes, funny things conducive to distribution thereof (Kamińska 2011, 61; Piskorz 2013).

In this work, the postulate to consider websites' orientation to the same subject and shared time frame while delineating the web's limits (Schneider, Foot 2008, 28), has only been partly fulfilled. However, the thematic homogeneity has been maintained as a result of focusing on Facebook fan pages dedicated to subdialects. Yet the requirement of a shared time frame was impossible to fulfil because each of the analysed pages has a different rate and frequency of publishing posts and time of existence.

\section{Computer-mediated communication (CMC)}

As the name suggests, computer-mediated communication needs to take place by means of a tool, a computer. Computer-mediated communication may be based on a text (a chat, a discussion forum, an e-mail etc.) or on a video (streaming a video, predominantly with the audio). The first type may be further divided into synchronous communication (taking place in real time, during a chat or in an instant messenger) 
and asynchronous communication (which permits a time lag, e.g. an e-mail or a discussion forum) (Chyrzyński 2012, 34-35) .

Attempts have been made to describe computer-mediated communication, which is recorded in writing, not only in the categories of writing but also speech. It shares some features with writing: it is permanent, spatially limited, the sender and the recipient are away from each other and anonymous, there is no eye contact, the context is not used and there is no fast feedback, the time between conveying and receiving the message makes it possible to carefully organise the text, abbreviations and acronyms. These features depends on the tools, e.g. a message is more carefully organised in the case of e-mails while in chats this is less important. What differentiates computer-mediated communication from speech is dynamics and volatility, loose syntax structures, ellipses and syntax streams, exchange of the sender and the receiver roles and there is less time to express one's thoughts in an organised way ${ }^{6}$ (Chyrzyński 2012, 41-53). Computer-mediated communication has some features of writing and contradicts others. The same holds true for the features of speech.

J. van Dijk has taken a slightly different stance; when describing the modes of symbolic communication (linguistic, non-verbal, iconic, logical and mathematical, musical) he noted that as new media appear in the linguistic mode, the importance of the audio-visual variant grows (texts accompanied by images and sounds) at the expense of the oral and written variants. What is more, the role of the iconic mode (videos, pictures, drawings, charts, windows and other graphic forms) is growing while the non-verbal mode (social-sign language) has disappeared wherever mediated communication, limited to transmission of speech, text and data, has replaced direct communication (van Dijk 2010, 295-296).

A face-to-face relation, known from direct communication, is replaced by an interface-to- interface relation. It is not fully direct communication but neither is it equivalent with communication based on print because "the interlocutors can communicate at the same time, not being close to each other" (Grzenia 2006, 65)7.

\footnotetext{
${ }^{5}$ In fact, technological determinants do not always indicate unambiguously that a specific communication tool is synchronous or asynchronous. Then, a reference can be made to the pragmatic aspect (the goal and the prevailing rules of using a specific medium), e.g. a chat permits a time lag but it is not accepted by the users and for this reason it is a part of synchronous communication (Chyrzyński 2012, 35-36).

${ }^{6}$ When describing online communication, M. Bugajski perceives the classical division of roles between a sender and a receiver in yet another way. He says that it is shaped in opposition to the official media and its nature is affected predominantly by the netizens' individualism. As a result, the division between senders and receivers, so clear in analog media, is blurred: "When communicating online, we are more of participants of communication processes than senders or recipients and these roles are not enforced by anyone" (Bugajski 2010, 141).

7 J. Grzenia defines proximity as circumstances in which eye or voice contact can be maintained; the first type of contact needs to be related to physical proximity, the other does not (Grzenia 2006, 65).
} 


\section{Linguistic codes on Slavic subdialectal fan pages}

An analysis of using linguistic varieties is expected to provide answers to the following questions: which code (literary or subdialectal) does the fan page author use? Is this the only code? Does it have relations with any other codes?

In the surveyed material, 8 literary codes were distinguished (English, Bulgarian, Czech, Macedonian, Polish, Serbian, Slovak, Ukrainian). The presence of English among fan pages dedicated to Slavic subdialects is quite surprising. However, initially as much as $90 \%$ of sites were managed in English; the drop to $60 \%$ is attributed to the growing trend of online locality (Krzysztofek 2008, 397). Messages in English may also stem from willingness to reach a larger audience which reflects a feature of the Internet, glocality: "every message, meant as local, may have a supra-local if not downright global range” (Krzysztofek 2008, 405).

A subdialectal code pertains to a smaller number of languages: Belarus, Bulgarian, Czech, Polish, Slovak and Ukrainian. It appeared exclusively on 17 fan pages; the literary code has been used as the only one on 25 pages. Clearly, while the analysed pages are meant to promote geographic varieties of a language, the fact that the content is targeted at large audiences (Motivation behind establishing subdialectal fan pages) induces the authors to use the literary variant.

A more interesting case are messages with heterogeneous varieties, including a mixed English-Slavic code (2 fan pages), e.g. Pirot (Serbian Cyrillic: Пupom) is a town and municipality located in south-eastern Serbia. (...) Циљ ове странице је прављење мреже људи који живе у Пироту, као и упознавање других људи са нашим градом (Пиротски говор), and a mixed dialectal-literary code (6 fan pages).

On the analysed pages, the interferences of language varieties may assume different forms: 1) separate spheres of life (e.g. a title - Subdialect Góralsko - and a description - Gwarom ô subdialect lo subdialect! - in the subdialectal code while the information is provided in the literary code), 2) co-existence of different language varieties in a single message following the pattern of a) equivalence, e.g. Лемколянд - лемківска сторінка для діти: гры, забавы, малюванкы, сьпіванкы. Lemkoland - łemkowska strona dla dzieci: gry, zabawy, malowanki, śpiewanki (Lemkoland), or b) using in the prevailing (literary) code a (subdialectal) quotation, e.g. Migawke kupujemy na krańcówce przy Górniaku, ale nie tylko! Po tódzku nazywamy setki miejsc i rzeczy $i$ nawet o tym nie wiemy... (Po łódzku), Dla tych, którzy woża się sałata, z nosa usuwaja tylko fluki apiać wiszcza (Gwara Białostocka). In all these cases, except for the rare type $2 \mathrm{a}$ ), the literary code prevails.

In the case of 3 fan pages, use of the Latin alphabet rather than the Cyrillic script is quite significant (Pa prostu; Howorymo; Wala). As M. Dąbrowska-Partyka indicates, in specific cases writing becomes "not only a (spelling) system but also a symbol of

${ }^{8}$ This supposition is confirmed by data about the community of Howorymo po swojomu. It consists of nearly 9,000 members; 7,568 of them are Poles, 294 are from the UK, 220 from Belarus, 106 from Belgium, 96 from the Ukraine, 89 from Germany (Czarnecka 2017). Therefore, approx. 16\% of the fan page's readers come from outside the country inhabited by the natural users of the subdialect. 
a specified set of values, a determinant of ethnic and cultural identity" (Dąbrowska-Partyka 2000, 178).

\section{Motivation behind establishing subdialectal fan pages}

The most frequent reason for keeping a subdialectal fan page is creating a community (cf. the diagram at the end of the chapter). To this end, the following arguments are typically put forward: shared pronunciation, e.g. Група за всички,които говорят на родопски диалект! (Родопски диалект), Też mówisz w 1 os. l. poj. "- przełamę się $w$ końcu - ogródek przekope jutro - nie ktamę mamy -- wieczorem się wykapę”? (Kielecki Dialekt), shared place of residence, e.g. Witojcie piyknie fsyćcy górole łod Żywca (Górole Żywieccy), the language being used by older generations, e.g. jon [prosty jazyk - B.O.] nasz, bo na jim razmaŭlajuć ni Muryny ŭ Afrycy, ale naszyja dziedki i baćki (Pa Prostu), quantifiers, e.g. Kożny maje takuju susiedku (Wala). Unlike the users of a traditional subdialect, this is not a community closed to strangers but rather, it frequently emphasises its open nature and encouragws others to join it, communicate with it, e.g. Dla Pudlaszukôw i dla wsiêch chto może $i$ ne z Pudlasza ale ciekawitsia! :) (Нoworymo), Циљ ове странице је прављење мреже људи који живе у Пироту, као и упознавање других људи са нашим градом (Пиротски говор), Jesteśmy Ślazakami. Nie jesteśmy żadna ukryta opcją. Poznajcie naszo godka. Latwiej będzie nam się porozumieć (Ślónsko godka), Zachęcam do komentowania postów (Gwara Góralsko).

Computer-mediated communication, which facilitates contact without direct interactions between people who live close to each other, leads to a situation when modern societies increasingly extend their time and space range (van Dijk 2010, 221). The natural environment, which used to be an important point of reference, has been replaced by social environments created by people (or the two intertwine) (van Dijk 2010, 223). Therefore, the spatial limitation (natural in the case of traditional subdialectal communities), is overcome on the analysed fan pages. The geographic dimension starts to act as a symbol around which the interested individuals gather; it is no longer a determinant of using this or other subdialect. This is because cyberspace is de-territorialized and therefore it can only be referred to in a metaphorical sense (Krzysztofek $2008,391)$. At the same time, in a situation of no unity of place, a specific group is actually united by a sense of belonging to a community (Greń 2008, 431), hence the above mentioned practices of individuals keeping subdialectal fan pages.

The second most popular reason for keeping the analysed pages are marketing activities $^{9}$. A subdialect or another variety of a language to which a fan page is dedicated are treated as goods of market value or used to promote products other than the subdialect itself. This group contains primarily offers of shops (e.g. gryfnie, Gwara Zagłębiowska, Z Bytomia), oftentimes referring to websites other than Facebook and activities related to linguistic normalization, e.g. Koli wy choczete doznatiś bôlsz chaj

\footnotetext{
9 They connect with one of the major goals of online communication (on top of willingness to inform and express) i.e. intention to affect the audience (Grzenia 2006, 95).
} 
bude wam pomoszczu storonka Pana Jana Maksymiuka svoja.org ! :) (Howorymo), Stuzę tė rada przy opracowywaniu tekstów gwarowych (Subdialect Góralsko). An interesting exception is an offer of managing events in Hantec slang: Nechte se bavit od toho, kdo to umi!! (Honza Hantec). It is difficult to decide if the individuals keeping fan pages with marketing in mind are genuinely interested in a subdialect or only in the possible profits.

The category of memory and the related activities are another reason for keeping a subdialectal fan page. Therefore, the intention of the authors of the analysed pages is to remind vocabulary that has slipped into oblivion, e.g. Да си припомним позабравени думи и изрази (Равногорски диалект), Всеки който си спомня истории и разговирни фрази (Брациговски диалект), tlumaczyt stare, często zapomniane stowa (Gwarat Góralsko) which oftentimes exist only in scholarly books, e.g. Zagladamy do starych słowników (Po łódzku), cultivating the language of the ancestors, e.g. [fanpage - B.O.] odkurza te [słowa - B.O.], którymi mówili nasi dziadkowie (Po łódzku), Poznaj codzienne słowa i słówecz używane przez naszych pradziadów! (Lwowski słówku). A community's culture, including a subdialect, is sometimes perceived as heritage, e.g. популяризація історії та культури Лемківщини як невід'ємного надбання українського культурного спадку (Молода Лемківщина). Observers of new media have noticed that contemporary societies, while very modern, are fascinated by time and the past as part of some sort of a retro cult. At the same time, digital media, including the Internet which is a source of this material, modify the old way of experiencing the past (Filiciak, Tarkowski 2014, 40-42). Nostalgia and memory are by nature subjective; by posting on fan pages dialectal words and memories of past events we externalize them, add inter-subjective character to them and make them a component of public memory. At the same time, a subdialect which can exist only in a dialogue, in a social environment, is perceived individually.

Another motivation to keep the analysed pages - protecting a subdialect - results from the above mentioned strong relation between a subdialect and the past. For example, Да съхраним автентичния равногорски диалект, който е единствен (Равногорски диалект), Siêta storonka dla wsiêch kotory (...) choczut kob jich mowa peretrywala! (Howorymo). On some of the analysed pages, protection, which is a defensive notion, is related to an offensive notion, propagating a subdialect, e.g. Zapraszamy do wspóltworzenia i promowania strony oraz idei twadokońcówkowej $w$ pierwszej osobie liczby pojedynczej (Kielecki Dialekt), kcem coby fsyćcy na tej stronie pisali gwarom, coby nie zabocyj nasej piyknej górolskij mowy!!! (Górole Żywieccy), популяризація історії та культури Лемківщини (Молода Лемківщина).

The ludic motivation of subdialectal fan pages may be attributed to both longing for the good old days, memories of youth - e.g. Ще се радваме да видим и стари снимки от минали събития... (Брациговски диалект), Да се посмеем и повеселим от сърце! (Равногорски диалект) - as well as the present, e.g. Hantec - písničky, povídání, soutěže... prostě správná volba pro Vaši zábavu! :-) (Honza Hantec), Warzymy-Wařymy, pichcymy,Srandujymy, wice łosprowjomy Po Našymu... (Warzymy). Some authors of the pages under scrutiny see the ludic potential of a subdialect itself, e.g. Zapraszam również wszystkich innych do zapoznania się z ciekawa, a często zabawna, dawna mowa Pałuczan (Pałuki). 


\section{Motivation behind keeping a subdialect fan}

\section{page}

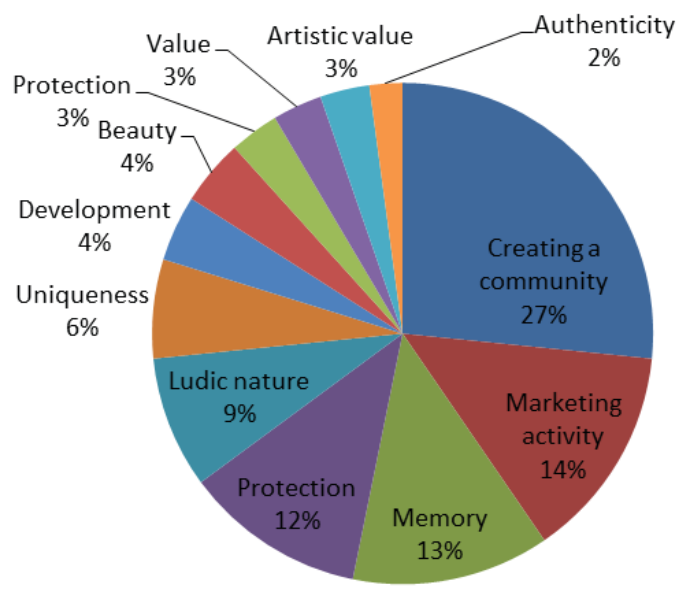

Oftentimes authors of fan pages are motivated by what they think of as attributes of a specific subdialect: uniqueness, e.g. Słowa, zwroty, powiedzenia - wyjatkowe, bo hajnowskie (Po hajnowsku), Celem naszej strony jest wychwycenie $i$ odnotowanie unikatowych zwrotów i nietypowego słownictwa (Dialekty Lubelszczyzny), beauty, e.g. Kwolmy się tym co momy nojpikniyjse!!!! (Górole Żywieccy), A co, niech będzie pięknie ładnie -- po łódzku! (Po łódzku), development (including standardisation), e.g. THE SITE IS DEVOTED to the standardization and development of the new written East Slavic language, Podlachian (Svoja), Osoby, które interesuja kwestie kodyfikacyjne gwar góralskich, zapraszam do grupy (Subdialect Góralsko), value, e.g. Да съхраним богатството на диалекта ни ! (Панагюрски диалект), Jon warty stolko, skolko usie druhija mowy świetu (Pa prostu), Byjmy dumni, ze my som górolami łod Żywca!!! (Górole Żywieccy), protection, e.g. Ni raz $i$ ni dva my czuli, szto prosty jazyk heto papsuta polska mowa, zaśmieczana rasiejskimi słowami, padrusyfikavana. (...) Prosta mowa heto ni jakajaści tam papsuta mieszanka (Pa prostu), Też mówisz w 1 os. l. poj. “- przełamę się w końcu (...)”? To nie błąd (Kielecki Dialekt), artistic value, e.g. Politická a poetická satira o naši Moravě (Poezie), Na jim nawat wierszy piszuć (Pa prostu), authenticity: Да съхраним автентичния равногорски диалект (Равногорски диалект), Cztery razy $w$ tygodniu prezentujemy jedno stowo prawdziwego Lodzermenscha (Po łódzku). 


\section{The Dawniej tutej... fan page as a subdialect dictionary}

An analysis has been carried out of the posts on Dawniej tutej... published between 11 February 2019 and 30 April 2020. Out of 131 posts, 100 (76\%) represented the dictionary type i.e. one tasked with presenting subdialectal vocabulary and explanation thereof.

The entry word and the accompanying lemmas are most frequently the first element of the graphic design. Its special role is also emphasised by a size, type or colour of the font different than that used in the remaining part of the text. Again, as with many other issues, there is no single solution that would be used consistently. It also happens that the lemma loses its initial position for the benefit of another element, e.g. it is preceded by a qualifier (wielkopolskie frazeologizmy, followed by a phrase stodki pamper), the defining element (cf. example 1) or a different element. Example 2 shows an interesting practice: here, the entry word is the last element and as such it is better remembered.

What is more, the text can be dominated by graphic elements like in example 3. The entry word $l u j$ written with a capital letter (not standard spelling), written in a bolded font, much bigger than the definitions, disappears next to a large male figure wearing a yellow, eye-catching T-shirt. This example also shows that, while a division into graphic and textual elements is useful in ordering an analysis, gets frequently blurred in the material; here, the man leans against the entry word.

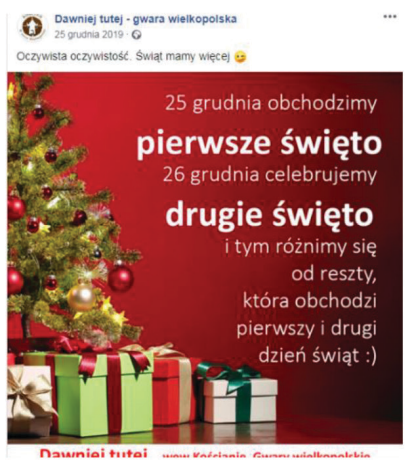

Example 1. (25 Dec.2019) $)^{10}$

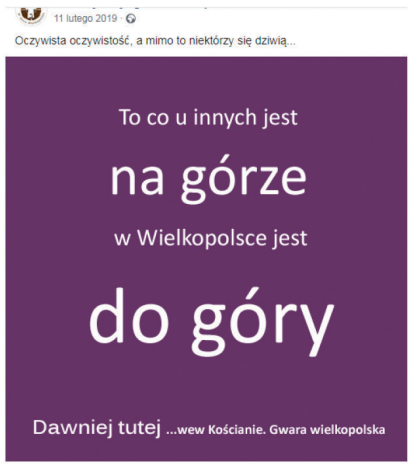

Example 2. (11 Feb.2019)

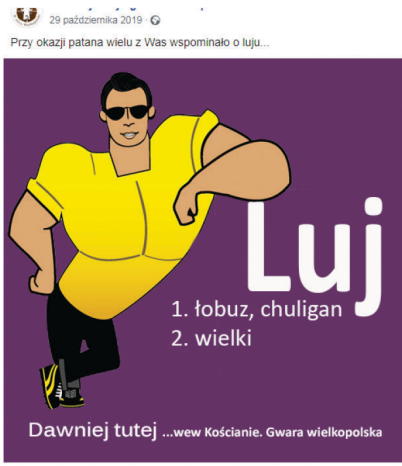

Example 3. (29 Oct.2019)

The figure from the first entry word is a canonical figure, known from scholarly dictionaries (jadaka 'a gob', berbelucha 'vodka of inferior quality, moonshine', gaska 'a narrow street or a blind alley', ciul 'a wimp, a klutz'), lemma in the form of morphological, lexical, phonetic, graphic variants (śrupok/śruber 'a floor scrubber', churchać churchlać 'to cough stubbornly', ruk cuk and rug cug 'quickly, in no time at all', piec kachowy kachlany kachlanny, pyry deptane duszone / krychane 'puréed potatoes'), multiple-word entries (glazejki z cicikiem 'gloves with fur', odbić bilet 'to

${ }^{10}$ In parentheses, the date of publishing a post was provided. 
punch a ticket', melona babka 'pound cake'), phrasemes (dać sobie $w$ tyte 'to get drunk', stodki pamper 'a person who likes sweets', myjcie statki za świeżego powietr$z a$ 'wash the dishes right after a meal').

To me, the accompanying lemma are entries enjoying the same status in the artwork. Therefore, the same font of the same size and colour was used; the arrangement does not suggest the main and subordinate entries. A scholarly dictionary would present each time a different entry whereas here the entries are amassed which stems from the semantic relations between the combined words.

The entry variants may enjoy the same status - these cases were described in the preceding subsection as the accompanying lemma; they may also be subordinate to the major variant which serves as an entry word. The first type of registering variants is more frequent (12 out of 16 posts). The second type includes bejmy 'money' and its synonyms baniole/banioki/szut 'coins, change' (8 Oct. 2019), a participle unorany 'soiled' and its synonyms usznujdrany, uślabrany, uślumprany, uszmudrany, uszmodrany, uśluńdrany (19 Aug. 2019), pyzy 'steamed yeast dumplings' and kluchy na łachu. The record is held by kwirlejka with 19 identified variants (example 4).

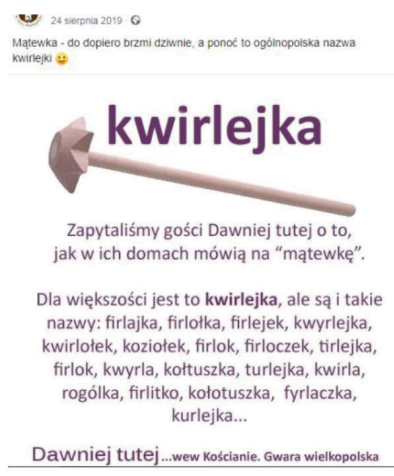

Example 4 (24 Aug. 2019)

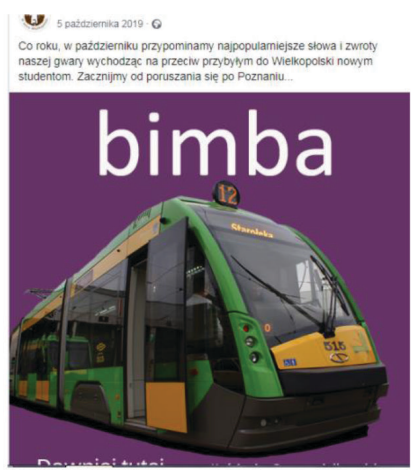

Example 5 (5 Oct.2019)
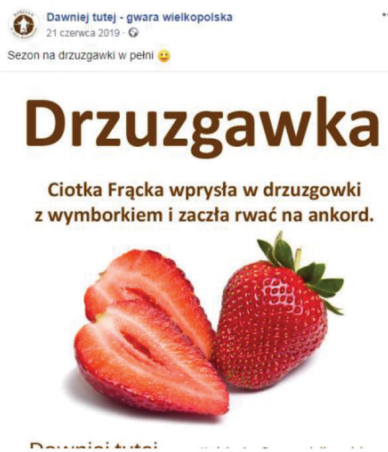

Example 6 (21 June 2019)

Synonymous definitions ${ }^{11}$ were most frequently used (63 entries), based on providing synonyms. While lexicographers are not very appreciative of this type of definitions, on Dawniej tutej... page this type of definition works best because the page users are either bilingual or diglossic, they know both the subdialectal and the general Polish codes. Indication of the general Polish synonym facilitates identification of the subdialectal word more quickly than when a real-meaning definition is provided. For example, haj has been defined as 'a knife'; the meaning is conveyed more quickly than the definition does: 'a cutting tool consisting of a metal blade fixed to a handle (...)'12. Use

${ }^{11}$ In the classification of the analysed material, W. Doroszewski's typology of dictionary definitions is used i.e. real-meaning, structural-semantic, structural, range-related, synonymous and grammatical definitions have been identified. Cases with an image definition or without a definition have been added. In the material in question, there were no structural or range-related definitions.

12 Entry nóż as in the SJPD. 
of contrast (often resulting from negation) is an interesting modification of a synonymous definition which indicates Wielkopolska's linguistic dissimilarity from the remaining parts of the country, e.g. Na podwieczorek nie podajemy ciasta tylko stodkie z dobra kawa (16 Nov. 2019), W Wielkopolsce kulka się kula a nie toczy (4.07.2019), To co u innych jest na górze $w$ Wielkopolsce jest do góry (11 Feb. 2019).

Interestingly, for practical reasons (limited space due to the artwork), not much text can be provided if it is going to be prominent and evident. Clearly, an author of an amateur dictionary published on a fan page does not seek precision of definitions as the art of lexicography would require; at play is the author's audience-orientation, his/ her communication competence and possible perception.

The number of real-meaning definitions is definitely smaller (21). This type of definition appears next to referents related to regional culture which do not have their equivalents in the general Polish culture. This is the reason why they convey detailed ethnographic information, e.g. ślepe ryby means 'potato soup served in Wielkopolska. As no meat was used to prepare it, it did not contain fat therefore it was 'blind' «ślepa»' (26 Feb. 2020), makiełki: 'A traditional dish served in Wielkopolska at Christmas Eve made from poppy seeds, dried fruit and nuts and wheat bread. Today, the bread is replaced by dumplings or pasta' (20 Dec. 2019). This rule applies less frequently to objects known outside the region but they do not have an individual, single-word designation, e.g. angielka means 'a kitchen coal stove, in an iron or tiled frame, with small legs' (17 Feb.2020), obktad - 'what is put on top of bread, e.g. cheese, cold cuts' (9 April 2019).

In a real-meaning definition, related to referents which serve as symbols of regional culture, there may be an expressive element (cudownie smakujace) and a quantifiable element ${ }^{13}$ (kultowe danie), e.g. Zamawiajac $w$ Wielkopolsce pyzy otrzymacie coś zupetnie innego niż w pozostałej części kraju. Dostaniecie cudownie smakujace, ugotowane na parze ciasto drożdzowe uformowane $w$ kształcie bułek. Podaje sie je z mięsem, sosem i kapusta. To kultowe danie kuchni wielkopolskiej. Takie pyzy nazywano niegdyś KLUCHAMI NA $\mathbf{L A C H U}$ (11 Oct.2019). Again, we are dealing with the authors' different attitude in scholarly and amateur compilations. The aim of the former is to convey objective knowledge. In the latter, the knowledge is combined with integration, creating a community. The aim is to reinforce a sense of belonging to a regional group enjoying good reputation.

The third most frequently used is the image definition (11), essentially foreign to scholarly dictionaries. If graphic elements (e.g. photos) appear in subdialectal dictionaries, most typically they are there to exemplify, to show whatever the definition conveys. However, an image definition completely replaces a verbal definition. Therefore, to some extent this is a reference to the saying "Anybody can see what a horse looks like" from Nowe Ateny by Benedykt Chmielowski from the first half of the $18^{\text {th }}$

\footnotetext{
${ }^{13}$ When analysing thematic online dictionaries dedicated to religious vocabulary, K. Czarnecka also indicated occurrence of definitions which are tainted by subjectivism (Czarnecka 2015, 25-30). Therefore, the author's subjective quantification would be a feature shared by amateur lexicographic works. This is a telling difference from professional dictionaries in which, according to P. Żmigrodzki, objectivism is an absolute criterion (Żmigrodzki 2008, 58).
} 
century (Urbańczyk 2000, 46). In Dawniej tutej... this type of definition attracts the biggest number of images which indicate a specific object unambiguously, e.g. a tramway (example 5) or a strawberry (example 6). This is the reason why the usefulness of image definitions is limited; they are hard to apply to abstract words, hyperonims, specific nouns without a tangible, substantial form, phrasemes, verbs, synsemantic words and that is only when I limit myself to the entries covered in Dawniej tutej.

A grammatical definition occurred in the studied material barely 5 times. It was used both with synsemantic parts of speech, e.g. wej '1. an exclamation to express admiration, astonishment, 2. reinforcing an element of speech' (1 April 2019), as well as auto-semantic ones. In the latter case, attention is paid to the inflection properties of the entry word rather than its meaning - cf.: wuja 'In Polish, wuja is the genitive and the accusative case of the word wuj. In Wielkopolska, wuja is the nominative case of the word wuj' (12 Aug. 2019).

There was also a single structural-semantic definition (W Wielkopolsce kulka się kula a nie toczy - 4 July 2019) and once, with an entry phrase chono ino na wino, no definition was provided ('the phrase does not require explanation' - 30 March 2019). What is more, as always, there are cases of entries defined by several types of definition simultaneously.

The status of graphic illustration is heterogeneous. On the one hand, it may be a sort of a graphic definition, presenting a specific object visually like an ostensive definition. On the other hand, it has the features of a quotation i.e. an illustration, an example of use. The first case was discussed in the previous section, let me now proceed with the second one. For example, the entry betki (12 Sept. 2019) is a hyperonim as betki is a collective reference to mushrooms which as such cannot have a single, realistic image. This is why the illustration shows a specific type of mushroom - the boletus. Yet another case is represented in example 7. The entry klara 'the sun' is illustrated by means of an arbitrary image of the sun with eyes and a smile.

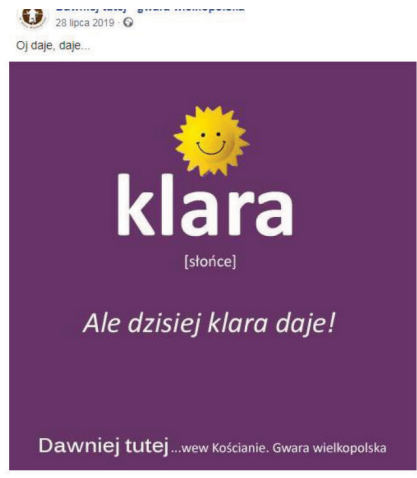

Example 7 (28 July 2019)

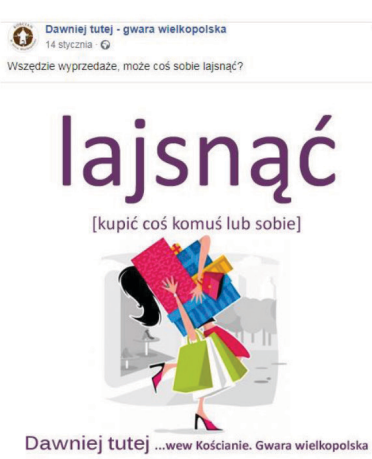

Example 8 (14 Jan.2020)

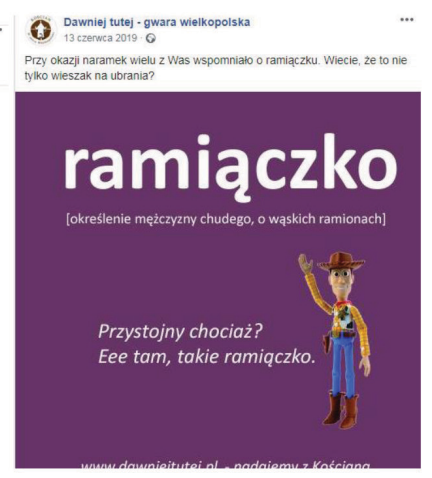

Example 9 (13 June 2019)

Quotations are used in only 28\% of the dictionary posts although their number would grow if the text from the non-graphic part were considered. The artwork from 
example 8 is preceded by a phrase Wszędzie wyprzedaże, może coś sobie lajsnąć? which serves as an introduction and a quotation. The quotes from the artwork consistently present subdialectal features from the other levels of language while the discussed example manifests only the lexical feature (the entry word). This is an indication of a different function of the non-graphic text.

Sometimes a quotation represents a different meaning of the lemma than the defined meaning, e.g. nowe lotko means 'a habit of walking from house to house with a pine or spruce twig' while the quote pertains rather to the twig: Pani gospodyni, nowe lotko w siyni. Jeśli chcecie łoglundować to musicie coś darować. Zielony gaj, koszyczek jaj... (21 March 2020). Sometimes a quote confirms a form other than the entry, e.g. dać sobie $w$ tyte 'to get drunk' and in a quotation Sprawit sobie tyte, ze jejku kochany! (30 March 2020).

However, these shortcomings are not the main objections to quotations, unlike the failure to provide the source. However, this is a drawback only from the point of view of scholarly lexicography while the audience and the amateur authors do not seem to mind. Nevertheless, this practice questions the possible use of this material as a source of subdialectal data.

Doubts arise because out of 28 posts with quotations, in 22 cases the quotations were taken from the Stownik gwary miejskiej Poznania (SGMP). To do justice, I need to take notice of the fact that the fan page's author mentioned the dictionary in the bibliography. However, the problem is that the SGMP registers the vocabulary of a specific variety of the Polish language (an urban subdialect) and with a specific territorial range (Poznań) while these parameters are non-existent on the fan page. Dawniej tutej... refers to itself as a page for the subdialect of Wielkopolska; the information part suggests the Poznań subdialect in its Kościan variety. There is no choice but to trust the fan page author's linguistic intuition and believe that the published entries belong to a collection shared by the subdialect from Poznań and the surrounds of Kościan.

Back to the quotations from the SGMP: let me emphasize that some of them are published without any changes (in total, 12 posts), e.g. in Dawniej tutej... and in the SGMP, churchać, churchlać - Churchla $i$ churchla, już tego suchać nie można (12 March 2020), sznupa - I niech se fifnie sznupe ośrupie (9 May 2019), klapsztula - Widziałeś jakie se klapsztule z szynka do roboty wziot? (7 April 2019), strużyny Mieli my tyle strużyn, że można było na nich proszczoka uchować (19 March 2019), while some of the quotes are changed. The changes include shortening of the original quotation to erase its literary origin in order to extend the use context, e.g. chachulic - Dawniej tutej...: On coś chachuli!, the SGMP: On coś chachuli! - oświadczyt. Papiery zgadzaty się, nie można było im nic zarzucić - On chachuli, panie poruczniku! - obstawat sierżant; gis gisówa - Dawniej tutej...: Szło na gisówe, bo niebo było obniesione jak diaski, SGMP: Szło na gisówe, bo nie było obniesione jak diaski, ale jo nic, tak jak stojotym - jade. A quotation may also be shortened because it contains definition elements revealed in a different way, for example in artwork. In the SGMP, the entry ramiaczko is accompanied by a quotation: Przystojny chociaż? - Eee tam, takie ramiaszko: ramionka waziutkie, nogi jak patyki, a post from 13 June 2019 includes only Przystojny chociaż? Eee tam, takie ramiaczko but the quotation is 
accompanied by artwork depicting cowboy Woody, a character from the Toy story films whose arms and legs are this and narrow (cf. example 9).

The changes to the original quotation (in total in 10 posts) consist in replacing words, e.g. haj - Dawniej tutej...: Tutej często haje szły w ruch, a Eda miol nawet knare (28.04.2020), SGMP: W tym luchaniu często haje szły w ruch, a Eda miot nawet knare; pierdoła z Gądek - Dawniej tutej...: Z wami, prześmiewcy, sie nieusionde jak jaki pierdoła z Gondek (28.01.2020), SGMP: Z wami, prześmiewcy, sie nie usionde jak opypłany pierdoła z Gondek; Dawniej tutej...: Nabolate jabza ino na mus sie nadajom (15.09.2019), SGMP: Te nabolate jabka to tylko na mus sie nadajóm; wygologolona - Dawniej tutej...: Łazi taka wygogolóno, że wszystko ji widać (13.02.2019), SGMP: $W$ szkole przy dzieciokach łazi wygogolóno, że wszysko ji widać.

Sometimes, the changes are superficial: adding a conjunction, a change to the spelling or the phonetic feature, e.g. galarepa - Dawniej tutej...: A galarepa po czemu? (16 July 2019), the SGMP: Galarepa po czemu?, migać - Dawniej tutej...: Pani, jak to teroz migajom trzeba wstydu niy mieć: dziewuchy cyckami trzynsóm, dupskiym kryncom (25 Feb. 2019), the SGMP: Pani, jak to teroz migajóm - trzeba wstydu niy mieć: dziewuchy cyckami trzynsóm, dupskiym kryncóm. It is hard to say if the changes have been introduced on purpose or result from careless copying of the text from the dictionary.

In the analysed material, there are also quotations which have no equivalents in the SGMP (6 in total). They tend to have a simple structure as indicated by the fact that they were heard or created by the posts' author, e.g. nie - To co wiara idymy, nie? (27 May 2019), Bier badejki, bo idymy sie bachać! (17 June 2019), klara - Ale dzisiej klara daje! (28 July 2019).

In the analysed material, four qualifiers have been identified. The first one emphasizes the integration nature of the vocabulary, e.g. kalafa 'it means both the face and the gob' (15 April 2020), with which the qualifier of the limited territorial range corresponds, e.g. ślepe ryby 'potato soup from Wielkopolska' (26 Feb. 2020), Wielkopolska phrasemes stodki pamper (20 Feb. 2020) because the mentioned limitation pertains to a regional community which is evaluated positively on the fan page. What is more, the qualifier may indicate a phraseme, e.g. Wielkopolska or Polish proverbs Wszyńdzie ploży, ale wew chacie najbarzy (26 Feb. 2019) coupled with lack of stylistic connotations in the regional variety of the Polish language, e.g. ciul 'according to the "Dictionary of the urban Poznan subdialect', the word was not perceived as a profanity' (4 Feb. 2020), pierdolić 'NB! In the Poznań subdialect, this word is not a curse word' (1 Feb. 2020). The last type is very interesting because qualifiers typically indicate stylistic connotations rather than lack thereof. However, this information is required in a situation of bilingualism (diglossia) when a language user can transfer a vocabulary connotation from one code to another.

The attempt at explaining the origin of a specific entry has been treated as the etymology. In the analysed material, there is a reason provided, e.g. ślepe ryby 'Potato soup from Wielkopolska. As no meat was used to prepare it, it did not contain fat therefore it was 'blind' «ślepa»' (26 Feb. 2020) or a folk-based explanation, e.g. in order to explain the entry macoszki 'pansies', reference is made to a story of a reader's grandma where the biggest petal is compared with a step-mother, two smaller ones to her daughters and the two last ones to step-daughters (16 May 2019). 
However, the sources of the borrowings are not provided even if the material contains numerous Germanisms, e.g. śrupok / śruber - from German der Schrubber 'a scrubbing brush', Co ja za to mogę? - from German was kenn ich dafür 'what can I do about it' 14 .

The collocations of the entry word, which in the artwork are subordinated to artwork, are deemed fixed combinations of words and were attributed a status subordinate to the lemma, e.g. a smaller font was used to record it and typically it was placed at the end of the text. This group contains both phrases subjected to phraseology, e.g. kalafa 'a face, a gob' and drzeć kalafe 'to shout, scream', kalafa sie komu drze 'to be sleepy, to yawn', mieć kalafe od ucha do ucha 'to have a big mouth, to be quarrelsome' etc. (15 April 2020) as well as combinations of words in their original meaning, e.g. szneka 'a sweet roll' and szneka z glancem 'a sweet roll with frosting' (14 Nov. 2019) although glanc means 'frosting'.

\section{Conclusions}

Notably, subdialects have increasingly marked their presence in the Internet. The fan pages analysed in this work show that the authors' motivations are diverse, ranging from an attempt to create a community, through marketing activities and willingness to protect or maintain subdialects up to the ludic aspects etc. At the same time, an analysis of language codes used on the analysed fan pages has shown that there is often a discrepancy between the authors' declarations and the practice: sites dedicated to subdialects and other geographic varieties of the language are kept in the literary variant or even in English. This is because of the fashion in which elements of subdialects operate in a new environment. The Internet is conducive to de-territorialization and creating groups based on shared interests rather than a territory. Another difference is the type of contact as compared against traditional subdialects: face-to-face communication has been replaced by interface-to-interface communication. Therefore, one can venture a cautious statement that in the analysed material, we deal with elements of traditional subdialects transferred to the Internet and operating there according to rules different than in the previous environment, not with online subdialects as such. However, this issue requires further research that will be carried out elsewhere.

On the other hand, amateur compilations of subdialectal vocabulary, while modelled by traditional lexicography, in the Internet are adapted to a new medium and the audience's competence and capabilities.

\section{Bibliography}

Bugajski M. (2010), Sytuacja komunikacyjna a zmiany językowe (rekonesans badawczy), [in:] Sytuacja komunikacyjna i jej parametry. I monografia z cyklu Sytuacje - komunikacja - konteksty, G. Sawicka (ed.), Bydgoszcz 2010, pp. 134-145.

\footnotetext{
14 Etymologies as in the SGMP.
} 
Cemborowski B. (2014), O promowaniu dialektu wielkopolskiego w Internecie. Raport z badań, "Adeptus. Pismo humanistów" 2014, no. 4, pp. 86-103. On-line access https://ispan.waw.p1/ journals/index.php/adeptus/article/view/a.2014.010/282 (5 July 2017).

Chyrzyński T. (2012), Język w Internecie. Formalne, semantyczne i funkcjonalno-pragmatyczne właściwości języka angielskiego i polskiego w komunikacji, Olsztyn.

Crystal D. (2005), The scope of Internet linguistics, first published in "American Association for the Advancement of Science meeting", February 2005, on-line access www.davidcrystal. com/?fileid=-4113 (31 July 2020).

Czarnecka K. (2015), O sposobach definiowania znaczeń leksyki religijnej w tematycznych stownikach internetowych, "Poznańskie Spotkania Językoznawcze" 29, pp. 17-35.

Czarnecka K. (2017), W poszukiwaniu tożsamości językowej - internetowa społeczność "Howorymo po swojomu”, Język w regionie - region w języku, B. Osowski, J. Kobus, P. Michalska-Górecka, A. Piotrowska-Wojaczyk (eds.), vol. 2, Poznań, pp. 65-84.

Dąbrowska-Partyka M. (2000), Pismo jako znak tożsamości, Język a tożsamość narodowa, M. Bobrownicka (ed.), Kraków, pp. 169-182.

Dubisz S. (2013), Dialekt i subdialect - integracja językowa - stylizacja subdialectal, [in:] ibid, Jezzkoznawcze studia polonistyczne (pisma wybrane, uzupetnione, zmienione), vol. I: Dialektologia i jej pogranicza, Warszawa, pp. 37-66.

Filiciak M., Tarkowski A. (2014), Dwa zero. Alfabet nowej kultury i inne teksty, Gdańsk-Warszawa.

Greń Z. (2008), Śląska lokalność w Internecie, Oblicza lokalności Ku nowym formom życia lokalnego, J. Kurczewska (ed.), Warszawa, pp. 431-441.

Grzenia J. (2006), Komunikacja językowa w Internecie, Warszawa.

Kamińska M. (2011), Niecne memy. Dwanaście wykładów o kulturze internetu, Poznań.

Kowalewska M. (2015), O rozumieniu i o braku zrozumienia dla memów, [in:] E-gatunki. Dziennikarz w nowej przestrzeni komunikowania, Warszawa, pp. 181-201.

Krzysztofek K. (2008), Wirtualna reterytorializacja: czy istnieje lokalność w cyberprzestrzeni, Oblicza lokalności Ku nowym formom życia lokalnego, J. Kurczewska (ed.), Warszawa, pp. 391-414.

Piskorz K. (2013), Internetowe memy, hieroglify XXI wieku, [in:] Wspótczesne media. Język mediów, I. Hofman, D. Kępa-Figura (eds.), Lublin, pp. 227-238.

Schneider S.M., Foot K.A. (2008), Sieć WWW jako przedmiot badań naukowych, Język@multimedia 2. $W W W-w$ sieci metafor. Strona internetowa jako przedmiot badań naukowych, A. Dytman-Stasieńko, J. Stasieńko (eds.), Wrocław, pp. 23-33.

Urbańczyk S. (2000), Słowniki i encyklopedie. Ich rodzaje i użyteczność, edition 4 changed and extended, chapter 3: Nowe stowniki, B. Sieradzka-Baziur, Kraków.

Żmigrodzki P. (2008), Słowo - słownik - rzeczywistość. Z problemów leksykografii i metaleksykografii, Kraków.

\section{Sources}

Dawniej tutej - Dawniej tutej - gwara wielkopolska, https://www.facebook.com/dawniejtutej/.

Dialekty Lubelszczyzny - Dialekty Lubelszczyzny, https://www.facebook.com/Dialekty-Lubelszczyzny-239956002840976/. 
Górole Żywieccy - Górole Żywieccy, Hej gronicki, gronicki, Wy muoje kuochane, https://www. facebook.com/GoroleZywieccy/.

gryfnie - gryfnie, https://www.facebook.com/gryfnie/.

Gwara Białostocka - Gwara Białostocka, https://www.facebook.com/SubdialectBialostocka/?fre$\mathrm{f}=$ pb\&hc_location=profile_browser.

Gwara Góralsko - Gwara Góralsko Skolnego Podholo, https://www.facebook.com/SubdialectGoralska/.

Gwara Zagłębiowska - Gwara Zagłębiowska dla Ciućmoków, https://www.facebook.com/subdialect.zaglebiowska.dla.ciucmokow/?fref=ts.

Honza Hantec - Honza Hlaváček - šiřitel brněnského hantecu, https://www.facebook.com/HonzaHantec/.

Howorymo - Howorymo po swojomu, https://www.facebook.com/howorymoposwojomu/.

Kielecki Dialekt - Kielecki Dialekt CK mowa miejscowa - twarde końcówki i gwara świętokrzyska, https://www.facebook.com/Kielecki-Dialekt-CK-mowa-miejscowa-twarde-ko \%C5\% 84c\%C3\%B3wki-i-subdialect-\%C5\%9Bwi\%C4\%99tokrzyska-228035863961466/.

Lemkoland - Lemkoland, https://www.facebook.com/Lemkoland/.

Lwowski słówku - Lwowski słówku, https://www.facebook.com/pg/lw1919/about/?ref=page_internal.

Pałuki - GWARA PALUCKA - jak kiejsiś nasze babusie i dziadusie godali, https://www.facebook.com/groups/538858839613644/.

Pa prostu - Razmaulaj Pa Prostu, https://www.facebook.com/Razmaulaj-Pa-Prostu-475917992505876/.

Poezie - Poezie moravského disentu, https://www.facebook.com/Poezie-moravsk\%C3\%A9ho-disentu-250093408232/.

Po hajnowsku - Leksykon hajnowski, https://www.facebook.com/pohajnowsku/.

Po łódzku - Mówimy po łódzku, https://www.facebook.com/mowimypolodzku/.

SGMP - Stownik gwary miejskiej Poznania, M. Gruchmanowa, B. Walczak (eds.), WarszawaPoznań 1997.

SJPD - Stownik języka polskiego, W. Doroszewski (ed.), vol. 1-11, Warszawa 1958-1969.

Ślónsko godka - Ślónsko godka dla Hanysów i Goroli, https://www.facebook.com/godejachim/.

Svoja - Svoja.org, https://www.facebook.com/Svoja.org/.

Wala - Wala - typowa susiedka, https://www.facebook.com/walaczka/.

Warzymy - Warzymy-Wařymy i pichcymy Po Našymu, https://www.facebook.com/groups/12710 $8857368336 /$ ?fref=ts.

Z Bytomia - Rubens byt z Bytomia, https://www.facebook.com/rubensZbytomia/.

Брациговски диалект - Брациговски диалект, https://www.facebook.com/groups/546627118742813/.

Молода Лемківщина - Молода Лемківщина, https://www.facebook.com/molodlem/.

Панагюрски диалект - Панагюрски диалект, https://www.facebook.com/groups/173265172718781/.

Пиротски говор - Пиротски говор, https://www.facebook.com/pirotski.govor/.

Равногорски диалект - Равногорски диалект, https://www.facebook.com/groups/1673453636243945/.

Родопски диалект - АЗ ГОВОРЯ НА РОДОПСКИ ДИАЛЕКТ, https://www.facebook.com/ groups/294722456731/. 